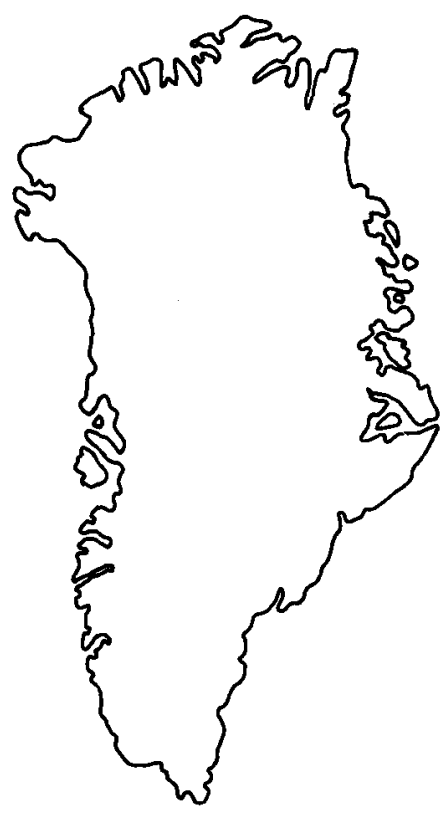

\title{
Are there Late Cretaceous unconformities in the onshore outcrops of the West Greenland basin?
}

\author{
T. C. R. Pulvertaft and J. A. Chalmers
}

\begin{abstract}
Unconformities seen in onshore sections often provide a clue as to the age of sequence boundaries seen in offshore seismic sections. Thus unpublished descriptions in industry reports of unconformities in the Upper Cretaceous of West Greenland have become of special interest since the initiation of a project involving a reinterpretation of all industry data acquired offshore West Greenland in the 1970s.

A reinvestigation of two of the most prominent of these unconformities, between Cenomanian and ?Campanian-Maastrichtian and between Cenomanian and ?'Senonian' respectively, confirmed that the unconformities exist, but cast doubt on the reliability of the palynological dating of the sediments above the unconformities. At both localities the sediments above the unconformities contain frequent layers of conglomerate with clasts of reworked sediments, in particular of dark mudstones like those seen in the Upper Cretaceous non-marine Atane Formation which underlies the unconformities. In these circumstances reworked pollen are likely to be encountered in the upper sections, making dating of these sections difficult. Elsewhere in the area Lower Paleocene sections are known to contain an almost exclusively Late Cretaceous palynomorph assemblage. Provisionally, therefore, the sections above the unconformities examined are placed in the Lower Paleocene, and the unconformities at their base are interpreted as being due to the end-Cretaceous movements known to have taken place in this part of West Greenland.
\end{abstract}

T. C. R. P. \& J. A. C., Geological Survey of Greenland, Øster Voldgade 10, DK-1350 Copenhagen K, Denmark.

The possibility that there are unconformities within the Upper Cretaceous sediments of West Greenland has important consequences for the interpretation of seismic data offshore, a task that one of us is engaged in (Chalmers, 1989, 1990). Calibration of the seismic data is primarily by means of the five wells drilled offshore West Greenland in 1976 and 1977 (Rolle, 1985). However, only one of these wells penetrated a significant thickness of pre-Tertiary sediments, and these consisted of mudstones disturbed by strong movements of shale diapirs (Rolle, 1985, pp. 1008-1009). This means that calibration of seismo-stratigraphic sequence boundaries in the pre-Tertiary section has to be by analogy with nearby basins. The most obvious nearby basin to use is the part of the West Greenland Cretaceous-Tertiary basin that outcrops in the Disko-Nûgssuaq-Svartenhuk area of central West Greenland.

As well as recording a faulting episode during the early Paleocene, interpretation of the seismic data shows that some of the pre-Tertiary sequences have cross-sections which suggest that they may be syn-rift sediments. It is obviously of some importance to date when rift episodes occurred in this region.

Early workers in the onshore West Greenland basin had been of the opinion that faulting was largely confined to the time around the Cretaceous-Tertiary boundary ("Laramide phase" - Rosenkrantz, 1940), with some evidence for late Albian-Cenomanian movement on the fault system that bounds the Cretaceous sediments on Upernivik $\emptyset$ and Qeqertarssuaq (Rosenkrantz \& Pulvertaft, 1969). However, an alternative view was put forward by a group of geologists from ARCO and Chevron oil companies, who undertook a joint investigation of the area in 1975 (Ehman et al., 1976). They reported evidence for important breaks in the stratigraphic record of the Upper Cretaceous at some localities, breaks which they believed reflected structural movements. Some of this evidence is entirely palynological, no breaks having been observed in the field at the localities in question (Alianaitsúnguaq, Pautût). At other localities, however, both field observations and palynological age determinations are cited in 


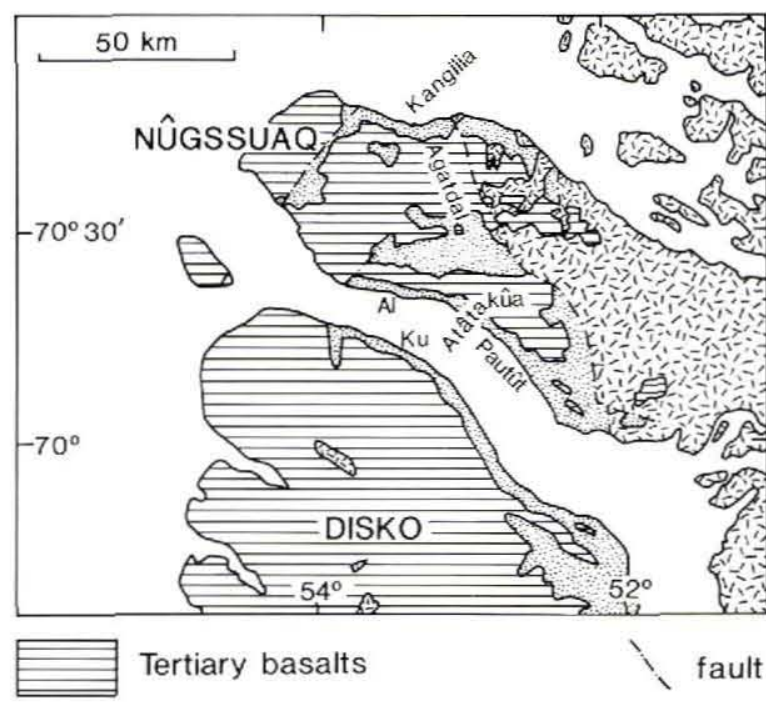

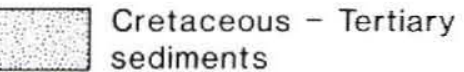

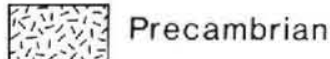

Fig. 1. Map of Disko and Nûgssuaq showing the position of the localities mentioned in the text. $\mathrm{Al}$ : Alianaitsúnguaq; $\mathrm{Ku}$ : Kugssinerujuk.

support of the unconformities being Upper Cretaceous.

It was therefore decided to make a field investigation of the two localities where Ehman et al. were most confident that unconformities exist. The sole aim was to examine the evidence for sedimentary breaks and unconformities. The localities in question are the west side of the outer part of the Atâta kûa gorge on the southern side of Nûgssuaq, and the gullies at Kugssinerujuk on the north side of Disko (fig. 1).

\section{Background}

Since Ehman et al.'s (1976) report is unpublished, and in order to put our observations and conclusions in context, a summary of the evidence for unconformities at Atâta kûa and Kugssinerujuk presented by Ehman et al. is now provided.

Atâta kûa. The section measured by Ehman et al. begins with $185 \mathrm{~m}$ of alternating sandstones and mudstones with coal belonging to the Atane Formation (this is the type locality for the Atane Formation) and dated as Middle Cenomanian. At $185 \mathrm{~m}$ in their section $(c .240 \mathrm{~m}$ a.s.1.) there is a well developed conglomerate which marks the base of a mudstone-dominated sequence 147 $\mathrm{m}$ thick (unit II of the present report); samples from this yielded an "excellent Maastrichtian palynomorph assemblage" (Ehman et al., 1976, p. 43; Ehman, 1977, p. 16). A sandstone-dominated sequence (unit III of this report) follows without any break noticed by Ehman's party in the field; a sample from near the base of this yielded "palynomorph assemblages identified as Upper Cretaceous-Lower Tertiary" but " $\ldots$ we interpret it as being Lower Danian" (Ehman et al., 1976, p. 38). Because Atane Formation strata are found up to over 600 $\mathrm{m}$ a.s.l. on the east side of the Atâta kûa gorge, Ehman et al. concluded that within "... a distance of less than one mile $[1609 \mathrm{~m}]$, approximately 1400 feet [ $427 \mathrm{~m}]$ of Atane Formation has been removed" prior to the deposition of the "Campanian-Maastrichtian" sequence (Ehman et al., 1976, p. 38). The obviously cross-cutting boundary seen in the west wall of the gorge (fig. 3) was regarded by Ehman et al. as part of the erosion surface separating the "Campanian-Maastrichtian" sequence from the middle Cenomanian strata below. The unconformity which separates "Campanian-Maastrichtian" strata from older sediments was taken as evidence for structural movement during this time. "This pre-Campanian-Maastrichtian unconformity is felt to be of more regional significance than the one observed at Kugssinerujuk which affects the Atane beds" (Ehman et al., 1976, p. 36).

Kugssinerujuk. At Kugssinerujuk, as also at Alianaitsúnguaq and Pautût, the hiatus suggested by Ehman $e t$ al. covers the Late Cenomanian - Turonian. "The strongest support for the occurrence of a local hiatus during Late Cenomanian-Turonian time is the section at Kugssinerujuk (D-3) on northern Disko Island. The geologists in the field recognized evidence for unconformities at the 900 and 920 foot [ 274 and $280 \mathrm{~m}$ ] levels in that section. Angular contacts of strata together with the presence of basal boulder conglomerates above the contacts were the bases for the interpretation. Biostratigraphical data appear to confirm the presence of the unconformity. The 880 foot [268 m] sample located below the unconformity zone yielded a good Middle Cenomanian assemblage. That at 959 feet $[292 \mathrm{~m}]$, above the unconformity, is described as good Senonian." (Ehman et al., 1976, p. 35).

\section{Observations from the 1989 field season}

\section{Atâta kûa}

A map of the west side of outer Atâta kûa gorge and a photograph of the west slope of the gorge are shown in figs 2 and 3. 


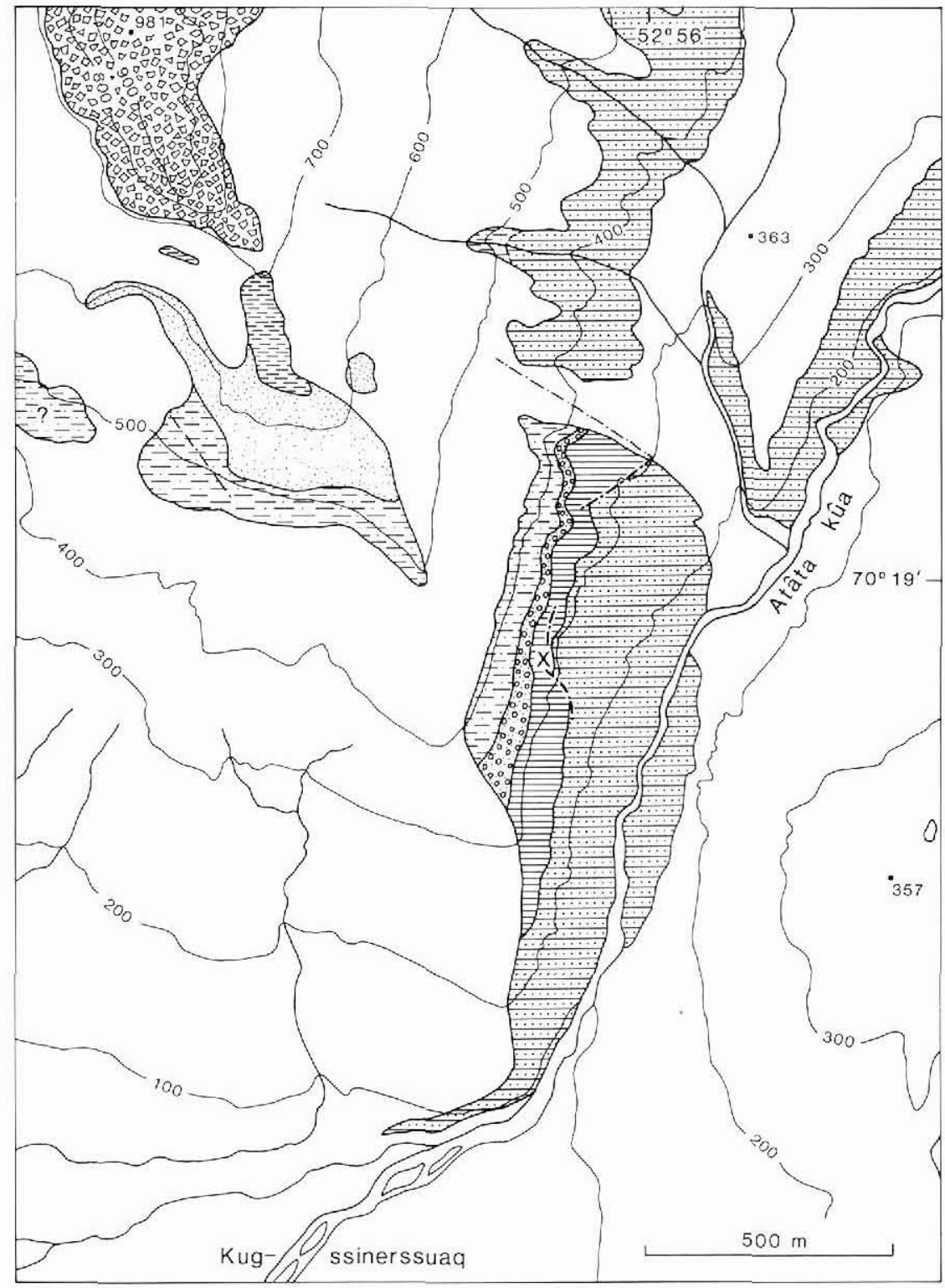

$\triangle D \Delta \theta$ Hyaloclastite

Q: 0 d breccia

$E==-$ Naujât

Member

Quikavsak

Member

Unit IV

0.000
0000
000

Ela Unit II

Unit I

(Atane $\mathrm{Fm}$ )

Fig. 2. Map of the outer part of the Atâta kûa valley showing the distribution of the units described in the text.

Succession. It was not possible to measure a continuous section anywhere on the slope because of the steep gradient and the loose condition of most outcrops. The succession described here is that on the west side of Atâta kûa going up the ridge from Kugssinerssuaq. Most of our observations were made with binoculars.

The section starts at about $80 \mathrm{~m}$ a.s.l. From here up to $240 \mathrm{~m}$ a.s.l. there is a succession of coarsening-upwards deltaic sequences with coal layers, interrupted by fluvial sands which often show distinct lateral bar growth development. The sediments constitute unit I for the purposes of the present report (see Table 1); they belong to the Atane Formation, and they resemble closely those at Pautût (Midtgaard \& Olsen, 1989). Available palynological information indicates that these strata are Cenomanian (Ehman et al,, 1976; Croxton, 1978).

At $240 \mathrm{~m}$ a.s.l. fissile mudstones of the Atane Formation are abruptly succeeded by conglomerate which lies on an obviously eroded and channelled surface. This conglomerate is at the base of a mudstone-dominated unit (unit II). The basal conglomerate is the first of several conglomerate layers, all matrix-supported and containing rounded cobbles of quartz up to $10 \mathrm{~cm}$ in length and also less rounded clasts of sandstone, mudstone and ?clay ironstone; the matrix and the intervening layers are of sand. This basal zone is succeeded by 
Table 1. Table showing different suggestions for the stratigraphic division and correlation of the strata on the west side of outer Atâta kûa, southern Nûgssuaq

\begin{tabular}{|c|c|c|c|c|}
\hline \multicolumn{3}{|c|}{ LITHOSTRATIGRAPHY } & \multicolumn{2}{|c|}{ AGE } \\
\hline \multicolumn{2}{|c|}{$\begin{array}{l}\text { Koch, } 1959 \\
\text { Rosenkrantz, } 1970\end{array}$} & $\begin{array}{l}\text { Informal units, } \\
\text { this paper }\end{array}$ & Ehman et al., 1976 & $\begin{array}{l}\text { This paper, based on } \\
\text { Rosenkrantz, } 1970 \text {, } \\
\text { Croxton, } 1978 \text { and } \\
\text { Hansen, } 1980\end{array}$ \\
\hline $\begin{array}{l}\text { Upper } \\
\text { Ataniker- } \\
\text { dluk Fm }\end{array}$ & $\begin{array}{c}\text { Naujât Mb } \\
\text { Quikavsak Mb }\end{array}$ & $\begin{array}{c}\text { Naujât Member } \\
\text { Quikavsak Member }\end{array}$ & $\begin{array}{l}\text { Paleocene } \\
\text { (unspecified) }\end{array}$ & $\begin{array}{l}\text { Mid-Late } \\
\text { Paleocene }\end{array}$ \\
\hline \multirow{2}{*}{\multicolumn{2}{|c|}{$\begin{array}{l}\text { Kangilia } \\
\text { Formation }\end{array}$}} & $\begin{array}{l}\text { Unit IV } \\
\text { Unit III }\end{array}$ & Early Danian & \multirow{2}{*}{ Danian } \\
\hline & & Unit II & $\begin{array}{c}\text { Campanian - } \\
\text { Maastrichtian }\end{array}$ & \\
\hline \multicolumn{3}{|c|}{ erosion } & \multicolumn{2}{|c|}{ hiatus } \\
\hline & $\begin{array}{l}\text { Atane } \\
\text { ormation }\end{array}$ & Unit I & $\begin{array}{l}\text { Middle } \\
\text { Cenomanian }\end{array}$ & $\begin{array}{l}\text { Late } \\
\text { Cenomanian }\end{array}$ \\
\hline
\end{tabular}

sandstone, which becomes interlayered with mudstones until eventually mudstone is the dominant lithology of the unit. Within the mudstone there are layers and lenses (?channels) of sandstone, and frequent erosional discordances. At around $280-290 \mathrm{~m}$ a.s.l. there are layers of matrix-supported conglomerate in which all the larger clasts appear to be of sedimentary rocks. The largest clast seen is more than a metre across and appears to be of sandstone (binocular observation); the layer in which this occurs is no more than about a metre thick.

At c. $320 \mathrm{~m}$ a.s.l. a sandstone-dominated unit, unit III, succeeds the mudstones of unit II. The base of unit III is strongly erosive, and conglomerate fills lows in this surface. Conglomerate recurs as channel-fill at several levels higher up in unit III. These conglomerates are usually clast-supported and polymict, with both sediment and basement (mainly quartz) clasts (binocular observation). Some dark (?mudstone) clasts exceed a metre in length.

The sandstone-dominated unit III passes rapidly at around $365 \mathrm{~m}$ into dark silty mudstone which alternates with thin layers of fine-medium sandstone (unit IV). There are also laminae and centimetre-size lenses of fine sand in the mudstone; low-angle cross-lamination was observed in the sandstone layers. No bioturbation was observed. Scree and solifluction material covers the slope above $c .420 \mathrm{~m}$ a.s.1., until fluvial sandstone of the Quikavsak Member is encountered at c. $540 \mathrm{~m}$. The Quikavsak Member, the lowest member of the Paleocene Upper Atanikerdluk Formation (Koch, 1959), fills a large channel cut into the underlying sediments.
Structural relations. Erosional unconformities without visible angular discordance occur at the base of units II and III.

Passing northwards along the steep slope from the ridge (fig. 3) the lower part of unit II abuts against the Atane Formation along a surface described as a steep erosion surface by Ehman et al. (1976), but interpreted as a fault (growth fault) by Hansen (1980) and Gunver K. Pedersen (personal communication, 1988). We have examined this surface at close quarters at two places, and have confirmed that it is a listric fault. From point $X$ (fig. 2) southwards the surface starts as an almost vertical surface trending $130^{\circ}$, and then curves into a gently westward-dipping surface in the Atane Formation mudstone just below unit II. It was not possible to trace the fault northwards from $\mathrm{X}$ where it disappears in poorly exposed mudstones. However, $350 \mathrm{~m}$ north of $\mathrm{X}$ a new fault separating unit II from the Atane Formation appears. This strikes $57^{\circ}$ and dips $55^{\circ}-65^{\circ}$ to NW. This fault disappears in shaley rubble to both $\mathrm{NE}$ and $\mathrm{SW}$. To the north-east it must be taken over by a NW-striking fault since Atane Formation sediments occur up to 480 $\mathrm{m}$ a.s.1., i.e. much higher than both units II and III, in the gullies to the north; this fault is not exposed.

Age of units II-IV and of structural movements. Although we have found no evidence of pronounced primary relief in the surface at the base of unit II, and can show that where the contact between the Atane Formation and unit II is steep, it is a fault, we agree with Ehman et al. (1976) that there is a marked break at the base of unit II. Furthermore it is clear that there was 
Fig. 3. View of part of the western slope of the outer Atâta kûa valley showing the units mentioned in the text.

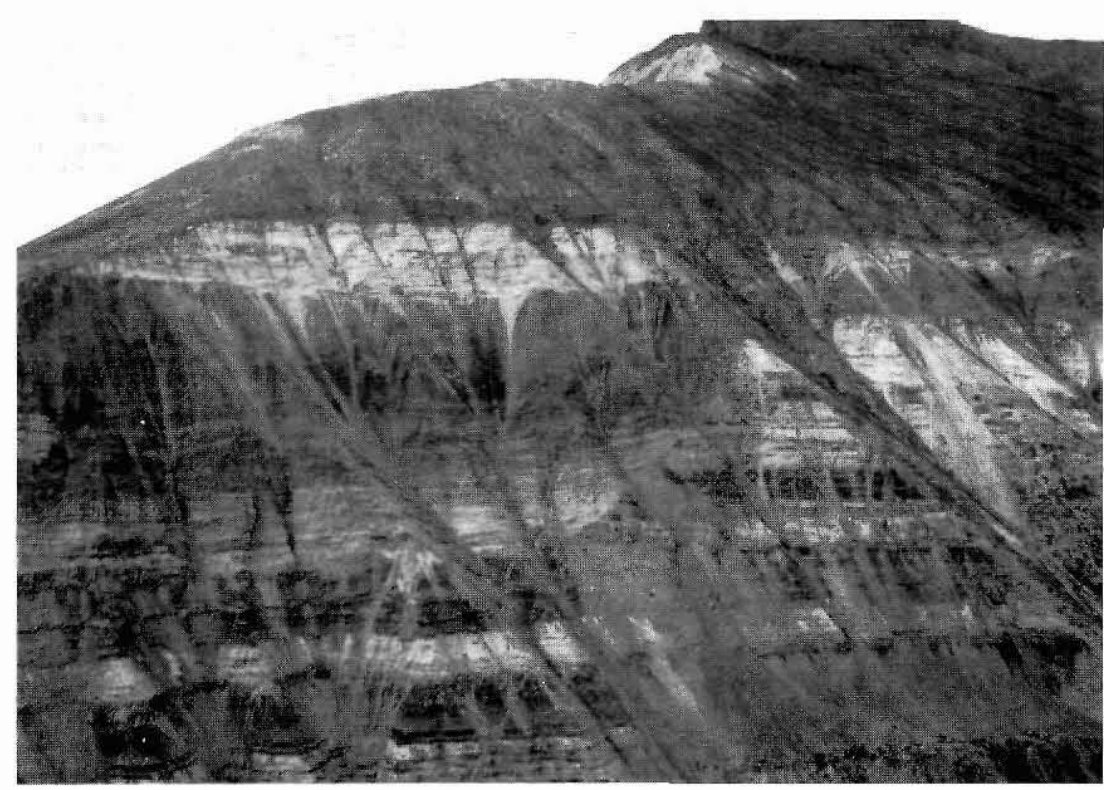

syn-sedimentary structural movement during deposition of units II and III.

As already mentioned, Ehman et al. regarded unit II as Campanian-Maastrichtian and unit III as Lower Danian. No other workers have commented specifically on the ages of these units. However Rosenkrantz (1970) correlated some of the slipped burnt shales a little west of Atâta kûa with the Danian Kangilia Formation on the north coast of Nûgssuaq on the basis of bivalves and gastropods collected in these shales. In fig. 4 in Henderson (1969) and again in Henderson et al. (1976, p. 351) Rosenkrantz placed the entire $300 \mathrm{~m}$ of sediments below the Quikavsak Member in the "marine Lower Danian" Kangilia Formation, but no details are provided. As regards unit IV, the only available information is from Croxton (1978, p. 31) who found mostly Upper Cretaceous palynomorph assemblages in samples from the unit; no dinoflagellates were found in these samples.

In evaluating this conflicting information it is apposite to comment on some sediments exposed between 400 and $500 \mathrm{~m}$ a.s.l. about $1300 \mathrm{~m}$ west of Atâta kûa. As was observed by Gunver K. Pedersen (field notebook, 1987), there are several levels of channel-fill conglomerates in these sediments (fig. 4). In these conglomerates all clasts above pebble size are of sedimentary rocks mainly sandstone, dark mudstone and clay ironstone. In addition to the channel conglomerates there are layers of 'shale breccia' consisting of angular to rounded dark mudstone clasts in a sand matrix, and in the intervening sandstones there are mudstone boulders up to more than two metres in length 'floating' in sand. The source

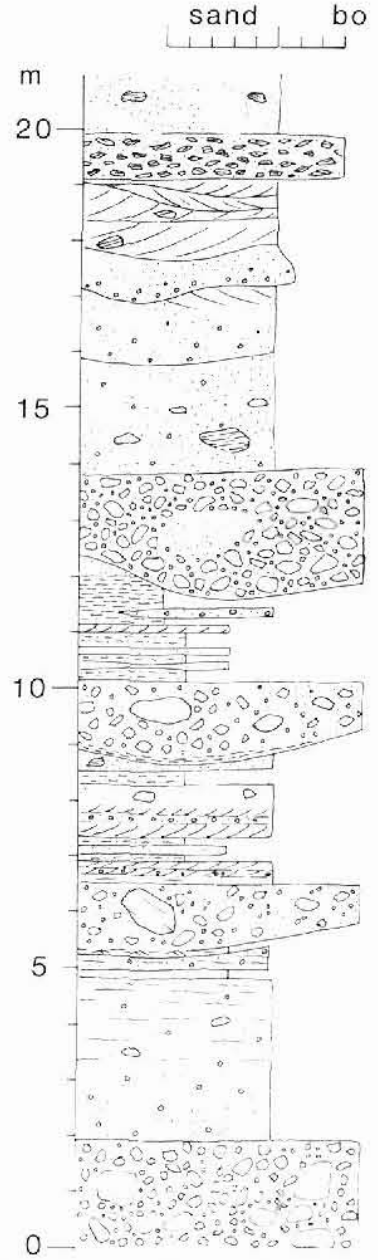

Fig. 4. Graphic log of part of the section c. $425 \mathrm{~m}$ a.s.l. above Atâ. 
of these clasts is likely to be the upper part of the Atane Formation that has been eroded away to the east. In this situation palynomorph assemblages are likely to be dominated by forms derived from the Atane Formation, and Late Cretaceous 'ages' are to be expected.

We believe that the 'classic' interpretation of $\mathrm{A}$. Rosenkrantz is probably correct: the sediments between 240 and $540 \mathrm{~m}$ a.s.1. (units II-IV) on the west side of the outermost Atâta kûa gorge are of Early Tertiary age although not necessarily as old as Early Danian (Hansen, 1980); the tectonic activity witnessed by faults, unconformities and very coarse conglomerates took place around the Cretaceous-Tertiary boundary or in earliest Tertiary time; there is no convincing evidence of mid-Late Cretaceous movements at Atâta kûa.

Our view that Ehman et al. (1976) did not take sufficient account of the possibility of palynomorph assemblages being redeposited from older strata receives support from information from Agatdal in central Nûgssuaq. Croxton (1978, pp. 42-43) specifically states that Maastrichtian palynomorph assemblages recovered from the Kangilia Formation here are derived, while Ehman et al., without any reservations record a "good assemblage of Campanian-Maastrichtian palynomorphs" from a section they measured in the Kangilia Formation in Agatdal. Hansen (1980, pp. 92, 97) later placed this section in the Upper Danian - Lower Selandian on the basis of dinoflagellate assemblages.

\section{Kugssinerujuk}

Good exposures, particularly of the Atane Formation, occur in a series of steep-sided gullies at Kugssinerujuk on the north side of Disko (fig. 1). These exposures do not appear to have attracted the attention of the Rosenkrantz expeditions, as they are not shown on the GGU 1:100 000 map 70 V.1 Syd - Qutdligssat. Ehman $e$ al.'s (1976) log thus appears to be the first and hitherto only record of the section here.

In the main gully, the lowermost undisturbed outcrop is at $120 \mathrm{~m}$ a.s.l. Between $120 \mathrm{~m}$ and c. $415 \mathrm{~m}$ a.s.l. the Atane Formation is exposed. This consists here of up to $25 \mathrm{~m}$ thick fining-upwards cross-bedded sandstone sequences alternating with finer-grained units within which there are coarsening-upwards sequences that terminate in fine-medium sand (fig. 5). Coal debris occurs in the thick sandstones. The mudstone between the top of the coarsening-upwards sequences and the base of the next thick sandstone is often very dark and rich in coalified plant material. Steep burrows about $3 \mathrm{~mm}$ in diameter occur in the coarsening-upwards sequences.

At c. $415 \mathrm{~m}$ a.s.l. in the main gully, and a little higher in the gully to the west, laminated mudstones of the

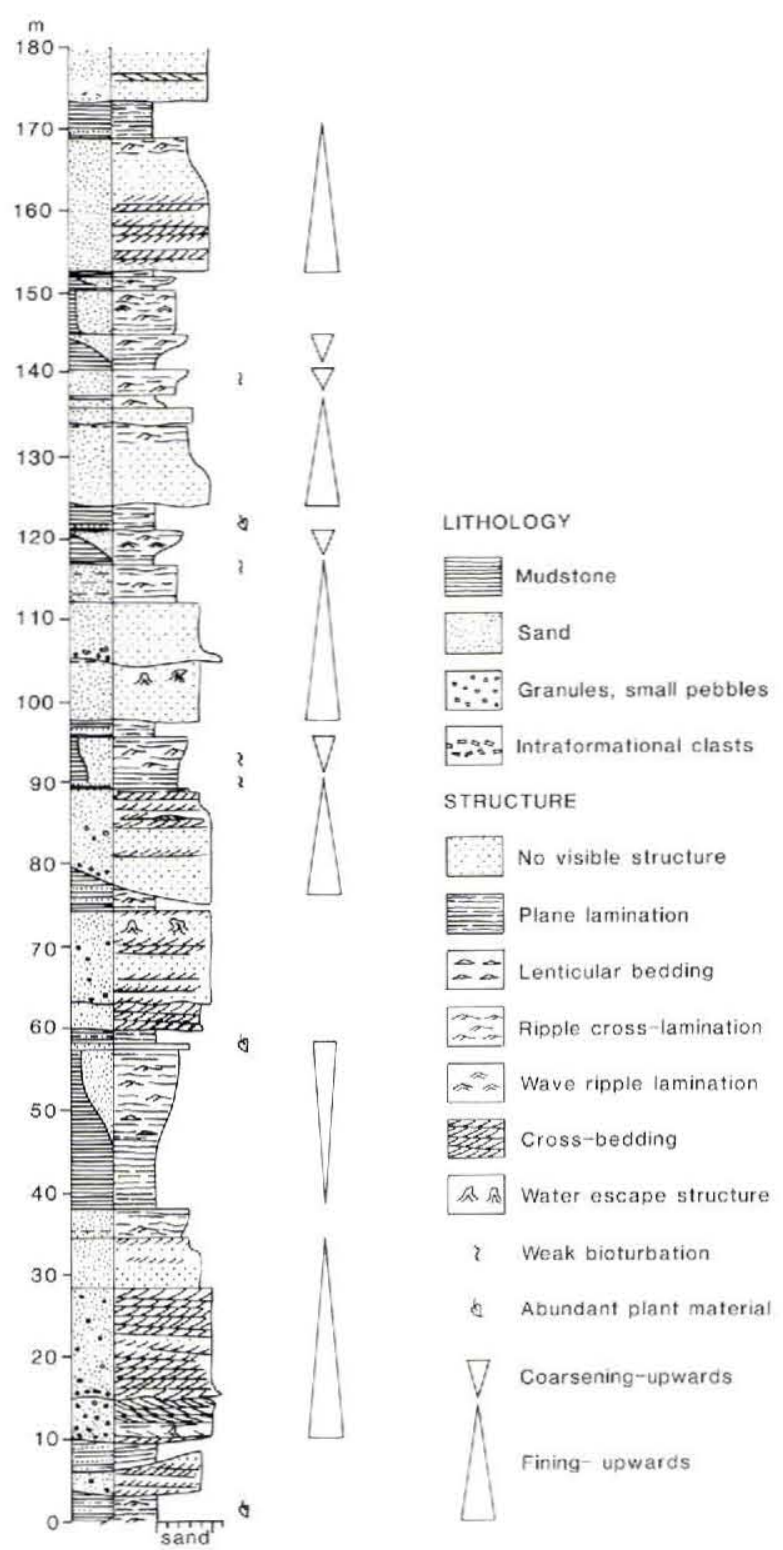

Fig. 5. Simplified graphic log of the lowest $180 \mathrm{~m}$ of the Atane Formation in the main gulley at Kugssinerujuk.

Atane Formation are overlain by conglomerate. The clasts in this conglomerate belong to two populations: rounded pebbles of quartz and clay ironstone-like material, and angular cobbles and boulders of sandstone, mudstone and heterolithic mudstone-sandstone. The base of the conglomerate is an erosion surface. The section above consists mainly of very poorly consolidated sandstone with occasional mudstone layers. In the lower part of the section there are at least four more horizons of conglomerate. In all of these the main, and sometimes only, lithology represented in clasts above 
pcbble size is dark mudstone. These mudstone clasts are matrix-supported, and there are isolated clasts of mudstone reaching more than a metre in length in the intervening sandstone layers. Some of the conglomerate horizons have a channelled base along which there is a thin lining of mudstone. The uppermost part of the conglomeratic and mudstone clast-bearing segment of the section is graphically represented in fig. 6 .

From fig. 6 and the foregoing paragraph it is clear that palynological dating of the time of deposition of the upper section (that above c. $415 \mathrm{~m}$ ) at Kugssinerujuk is fraught with uncertainties. All the larger clasts in the conglomerates are of redeposited sedimentary rocks. Either they are intraformational or, just as likely, they were derived by erosion of the upper part of the Atane

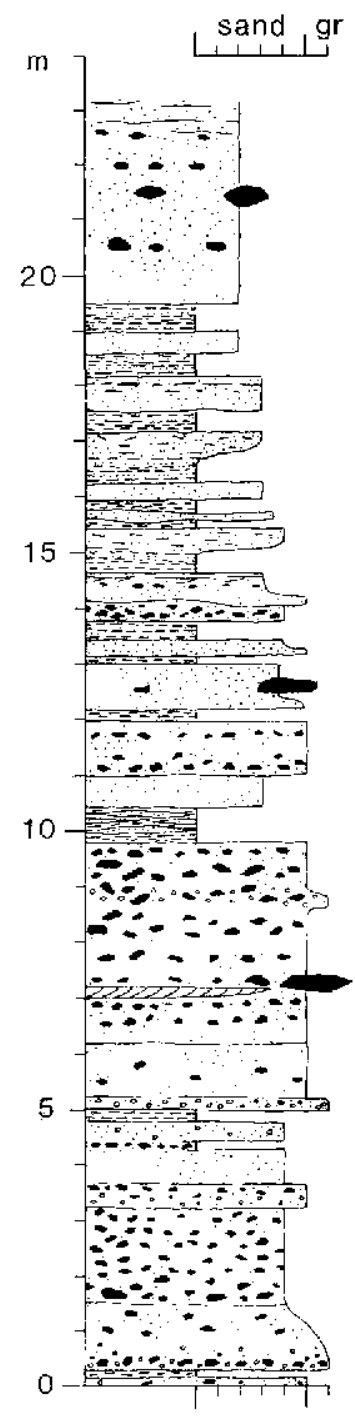

Fig. 6. Graphic log of a small part of the upper section at Kugssinerujuk. Black denotes dark mudstone clasts.
Formation. The preponderance of mudstone clasts indicates that all the mudstone in the section is likely to be contaminated by, if not solely derived from, previously deposited mudstones. In these circumstances palynomorphs in these sediments are likely to be derived, and palynomorph ages to be the age of the source area, not the time of deposition of the section. Given the possibility that the source was not intraformational but was the upper part of the Atane Formation, the Senonian age quoted by Ehman et al. (1976) for the palynomorph assemblages in the upper section should not be immediately accepted as indicating the age of deposition of this section.

Lacking other evidence for the age of the upper section at Kugssinerujuk, we are forced to resort to analogy. The section above $c .415 \mathrm{~m}$ at Kugssinerujuk has much in common with that above $400 \mathrm{~m}$ on the slope $1300 \mathrm{~m}$ west of Atâta kûa, and the structural situation is similar to that west of Atâta kûa. For this reason we believe that the upper section at Kugssinerujuk should be correlated with what has been called Kangilia Formation on the west side of Atâta kûa, and that the age of the section is Early Tertiary. The structural movements represented by the break at the base of the upper section at Kugssinerujuk and by the coarse conglomerates above belong to the end Cretaceous - early Tertiary phase of tectonic activity that has left its mark over much of the Disko-Nûgssuaq area.

\section{Conclusion}

Our investigations in the field combined with what can be gleaned from unpublished reports and theses indicate that most of the unconformities that have been recorded within the Upper Cretaceous of West Greenland are in fact at the base of the Tertiary. We suggest that it is the incorrect dating of the Early Tertiary strata overlying these unconformitics that has lead to the suggestion that the unconformities occur within the Upper Cretaceous. The palynomorph assemblages that are the basis for these incorrect dates are derived, the material stemming from crosion of the Upper Cretaceous Atane Formation. The unconformities in question are due to tectonic movements at the end of the Cretaceous or in earliest Tertiary time, i.e. belong to the "Laramide phase" suggested by Rosenkrantz (1940).

The only good evidence for an unconformity within the Upper Cretaceous of West Greenland is still that provided by Birkelund (1965, p. 20), who recorded Maastrichtian ammonites in poorly exposed strata that lie above a non-marine Albian-Cenomanian sequence east of the major fault east of Kangilia (fig. I) (Ehman et al., 1976; Croxton, 1978). Ziegler (1988, plate 28) 
shows a rift-induced erosional hiatus between the Campanian and Maastrichtian on the West Greenland shelf, without giving any reference. This is puzzling, as the only hiatus recorded on the shelf, other than in seismic profiles, is that between Paleocene and Campanian in the Kangâmiut well (Rolle, 1985).

Confirmation of our interpretation of the relations described by Ehman et al. (1976) can only be achieved by palaeontological means. We have collected a number of samples from above the unconformities in the hope that at least one will yield diagnostic Early Tertiary palynomorphs.

Acknowledgement. We are grateful to Gunver K. Pedersen for providing us with notes and photographs from her 1987 visit to the Atâ area in southern Nûgssuaq. Her photographs in particular were very useful for recording locations on steep slopes.

\section{References}

Birkelund, T. 1965: Ammonites from the Upper Cretaceous of West Greenland. Bull. Grønlands geol. Unders. 56 (also Meddr Grønland 179(7)), 192 pp.

Chalmers, J. A. 1989: A pilot seismostratigraphic study on the West Greenland shelf. Rapp. Grønlands geol. Unders. 142, $16 \mathrm{pp}$.

Chalmers, J. A. 1990: Re-evaluation of the geology of the southern West Greenland shelf - Project VEST SOKKEL. Rapp. Grønlands geol. Unders. 148 (this volume).

Croxton, C. A. 1978: Report of field work undertaken between $69^{\circ}$ and $72^{\circ} \mathrm{N}$, central West Greenland in 1975 with preliminary palynological results. Open File Rep. Grønlands geol. Unders. 78-1, 88 pp.

Ehman, D. A. 1977: Report on ARCO 1976 West Greenland field party. ARCO Oil Producing Inc., $31 \mathrm{pp}$.
Ehman, D. A., Sodero, D. E. \& Wise, J. C. 1976: Report on ARCO and Chevron Groups 1975 West Greenland field party. ARCO Greenland Inc., 84 pp.

Hansen, J. M. 1980: Stratigraphy and structure of the Paleocene in central West Greenland and Denmark. Unpubl. lic. scient. thesis, Geological Institute, Univ. Copenhagen, 156 pp.

Henderson, G. 1969: Oil and gas prospects in the CretaceousTertiary basin of West Greenland. Rapp. Gronlands geol Unders. 22, 63 pp.

Henderson, G., Rosenkrantz, A. \& Schiener, E. J. 1976: Cretaceous-Tertiary sedimentary rocks of West Greenland. In Escher, A. \& Watt, W. S. (edit.) Geology of Greenland, 341-352. Copenhagen: Geol. Surv. Greenland.

Koch, B. E. 1959: Contribution to the stratigraphy of the non-marine Tertiary deposits on the south coast of the Nûgssuaq peninsula, northwest Greenland. Bull. Grønland geol. Unders. 22 (also Meddr Grønland 162, 1), 100 pp.

Midtgård, H. \& Olsen, T. 1989: Sedimentological studies in the Upper Cretaceous coal-bearing strata of southern Nûgssuaq, central West Greenland. Rapp. Grønlands geol. Unders. 145, 32-37.

Rolle, F. 1985: Late Cretaceous - Tertiary sediments offshore West Greenland: lithostratigraphy, sedimentary evolution, and petroleum potential. Can. J. Earth Sci. 22, 1001-1019.

Rosenkrantz, A. 1940: [Oversigt over den samlede Lagfølge paa Nûgssuaq]. Meddr dansk geol. Foren. 9, 660-662.

Rosenkrantz, A. 1970: Marine Upper Cretaceous and lowermost Tertiary deposits in West Greenland. Meddr dansk geol. Foren. 19, 406-453.

Rosenkrantz, A. \& Pulvertaft, T. C. R. 1969: CretaceousTertiary stratigraphy and tectonics in northern West Greenland. Mem. Am. Ass. Petrol. Geol. 12, 883-898.

Ziegler, P. A. 1988: Evolution of the Arctic-North Atlantic and the western Tethys. Mem. Am. Ass. Petrol. Geol. 43, 197 pp. and 30 plates. 